\title{
Response Surface Optimization of Enzymatic Hydrolysis of Sugar Beet Leaves into Fermentable Sugars for Bioethanol Production
}

\author{
Natthiporn Aramrueang1,2, Steven M. Zicari1 ${ }^{1}$, Ruihong Zhang ${ }^{*}$ \\ ${ }^{1}$ Department of Biological and Agricultural Engineering, University of California, Davis, CA, USA \\ ${ }^{2}$ Department of Biotechnology, Faculty of Science, Mahidol University, Bangkok, Thailand \\ Email: *rhzhang@ucdavis.edu
}

How to cite this paper: Aramrueang, N., Zicari, S.M. and Zhang, R. (2017) Response Surface Optimization of Enzymatic Hydrolysis of Sugar Beet Leaves into Fermentable Sugars for Bioethanol Production. Advances in Bioscience and Biotechnology, 8, 51-67. https://doi.org/10.4236/abb.2017.82004

Received: November 21, 2016

Accepted: January 22, 2017

Published: January 25, 2017

Copyright (๑) 2017 by authors and Scientific Research Publishing Inc. This work is licensed under the Creative Commons Attribution International License (CC BY 4.0).

http://creativecommons.org/licenses/by/4.0/

(c) (i) Open Access

\begin{abstract}
Sugar beet leaves are the major crop waste from sugar beet production, while the unused leaves contain a high number of sugars and polysaccharides. The effects of different enzyme products (cellulase, Cellic CTec2; xylanase, Cellic HTec2; and pectinase, Pectinex Ultra SPL) were determined during high-solids enzymatic hydrolysis of sugar beet leaves at $10 \%$ total solids (TS) content. Response surface methodology was used to study the effects of enzyme loadings during the hydrolysis of sugar beet leaves for producing fermentable sugars. It was found that both cellulases and pectinases are important enzymes for the hydrolysis of sugar beet leaves. Enzyme loading and reaction time were important factors. Based on the amount of sugars released, a maximum sugar conversion of $82 \%$ was achieved after $72 \mathrm{~h}$ of hydrolysis using 30 filter paper unit (FPU) $\mathrm{g}^{-1}$ glucan for cellulase and 150 polygalacturonase unit (PGU) $\mathrm{g}^{-1}$ polygalacturonic acid for pectinase, or $37 \mathrm{FPU} \mathrm{g}^{-1}$ glucan for cellulase and 100 PGU $\mathrm{g}^{-1}$ polygalacturonic acid for pectinase. The corresponding sugar yield and sugar concentration were $0.35 \mathrm{~g} \cdot \mathrm{g}^{-1} \mathrm{TS}$, and $35 \mathrm{~g} \cdot \mathrm{l}^{-1}$, respectively. Sugar conversion ranged from 59\% - 70\%, 68\% - 80\%, and 74\% - 82\% after $24 \mathrm{~h}, 48$ $\mathrm{h}$, and $72 \mathrm{~h}$ of hydrolysis depending on the design conditions.
\end{abstract}

\section{Keywords}

Enzyme Hydrolysis, Sugar Beet Leaves, Response Surface Methodology, Sugar Conversion

\section{Introduction}

Sustainable and low-cost biomass feedstock is important for production of bio- 
fuels and other valuable products in a bio-based economy. At present, commercial bioethanol fuel is primarily produced from corn (Zea mays) in the US, China, and Canada; sugarcane (Sacchrum officinale) in Brazil; sugar beet (Beta vulgaris) in France; wheat (Triticum aestivum) in China and Canada; and cassava (Manihot esculenta) in Thailand [1]. Most of current research and technology development for bioethanol production is focused on the use of agricultural and food residues as feedstock in order to reduce the feedstock cost and alleviate the competition between fuel and food/feed.

Plant leaves are a significant biomass resource that remains to be explored. Compared to corn stover and wheat or rice straw, leaves are normally easier for biodegradation, and contain more pectin and protein, and less lignin. They contain considerable amounts of cellulose, hemicellulose and pectin, which can be depolymerized by chemicals and/or enzymes into sugar monomers and sugar acids [2] [3]. The sugar streams obtained from leaf hydrolysates can be converted into bioethanol and other valuable products such as xylitol, organic acids, and industrial enzymes [2] [3] [4] [5]. Leaves are good feedstock for bioconversion processes. In addition, the protein in leaves can be extracted as a valuable byproduct for food and feed applications [6] [7] [8].

Sugar beet leaves are byproducts of sugar beet, which is one of the major sugar crops and has become a significant energy crop in several countries. In the United States, nearly 72 million metric tons (wet basis) of sugar beet were produced in 2010 with an average yield of 62 metric ton ha ${ }^{-1}$ [9]. In Europe, sugar beet contributes to thirty percent of bioethanol fuel production, which was over 1.2 billion liters in 2010 [10]. Sugar beet leaves account for $40 \%-50 \%$ of total biomass on wet weight basis and could potentially be a significant biomass feedstock for biofuel production. In the US, the maximum leaf yield is estimated at around 50 metric ton ha ${ }^{-1}$ on wet weight basis or $6-7$ metric ton ha ${ }^{-1}$ on dry weight basis [11].

In order to produce ethanol from leaves by using commercially available yeast, such as Saccharomyces cerevisiae, enzyme hydrolysis is a necessary step for releasing the fermentable sugars and other compounds from the leaves. Much research has been reported in the literature on the hydrolysis and fermentation of sugarcane leaves due to the considerable amount of such biomass available from the commercial production of sugarcane for bioethanol conversion [3] [5] [12]. Sugarcane leaves are composed mainly of cellulose (36\%), hemicellulose (21\%), and lignin (16\%) on dry weight basis [13]. Previous studies on the hydrolysis of sugarcane leaves successfully employed the synergistic effects of cellulase and hemicellulase mixture to achieve high sugar conversion during hydrolysis process. According to da Silva's study, enzymatic hydrolysis of ball milled pretreated sugarcane leaves using cellulase with a supplement of $\beta$-xylosidase showed $77.6 \%$ and $56.8 \%$ of glucose and xylose conversion, respectively [14]. Ferreira-Leitao et al. conducted the enzymatic hydrolysis of steam-pretreated sugarcane leaves into glucose, which lead to a $97.2 \%$ theoretical yield through the use of cellulase and $\beta$-glucosidase [15]. 
However, leaf biomass from sugar beets and other important energy crops has not yet been much explored. Currently available commercial enzyme preparations have been mainly developed for corn stover and grasses. Research is needed to determine the best enzymes and their dosages for herbaceous leaves that have high contents of cellulose, hemicellulose, and pectin but low content of lignin [16] [17] [18]. Sugar beet leaves are composed mainly of cellulose (13\% $18 \%)$, hemicellulose $(11 \%-17 \%)$, and pectin $(14 \%-18 \%)$ with small amount of lignin (5\% - 6\%) [19] [20] [21]. Although the study of enzyme hydrolysis of other herbaceous leaves is not available, previous studies on high pectin-containing biomass, such as sugar beet pulp and citrus waste, showed the importance of pectinase enzyme during hydrolysis process [22] [23].

In this work, sugar beet leaf was investigated as feedstock for the production of fermentable sugars and valuable co-products with the goal of developing an efficient enzymatic hydrolysis process at high solids loading. The primary objective of this study was to investigate the effect of enzyme addition during the hydrolysis of sugar beet leaves, using different enzyme mixtures that consist of cellulase, xylanase and pectinase. A five-level rotatable central composite design was used to study the effect of enzyme loadings for a maximum conversion of sugar beet leaves to fermentable sugars.

\section{Materials and Methods}

\subsection{Materials}

Sugar beet leaves (Beta vulgaris) from mature ECN115 variety beets (seeds provided by KWS Betaseed, Inc.) were collected from the research farm of the University of California, Davis. Some of the fresh leaves were randomly picked and processed for compositional analysis. The remaining leaves were stored in a sealed container at $4^{\circ} \mathrm{C}$ for enzymatic hydrolysis immediately after determining compositional data. For compositional analysis, fresh leaves were chopped, ground using a food processor, and dried using a freeze drier (FreeZone Freeze Dry System, LABCONCO, MO). The dried sample was milled with a 40-mesh Wiley mill (Thomas Scientific, NJ). For enzymatic hydrolysis, the leaves were chopped and ground using a food processor. Fresh and dried samples were analysed for moisture (MC), total solids (TS), and volatile solids (VS) contents.

\subsection{Compositional Analysis}

Extractive, structural carbohydrate, and lignin contents for sugar beet leaf samples were determined following NREL Chemical Analysis and Testing Standard Procedures [24] [25]. The extractives were determined by extracting the biomass with water and ethanol for eight and sixteen hours, respectively, using a Soxhlet apparatus. The supernatants were vacuum-filtered and collected for analyses of sugars and sugar acids. The filtered solids were freeze-dried, followed by acid hydrolysis with strong sulfuric acid $\left(72 \% \mathrm{H}_{2} \mathrm{SO}_{4}\right.$, w/w) at $30^{\circ} \mathrm{C}$ for one hour, and diluted sulfuric acid $\left(4 \% \mathrm{H}_{2} \mathrm{SO}_{4}\right.$, w/w) at $121^{\circ} \mathrm{C}$ for one hour in an autoclave. The autoclaved hydrolysis solution was vacuum filtered and analysed for lignin and 
structural carbohydrate contents.

The concentrations of sugars in supernatants were determined using a high performance liquid chromatography (HPLC) system (Shimadzu, Columbia, MD) equipped with an ion exchange Aminex HPX-87P column (Bio-Rad Laboratories, Hercules, CA), micro-guard column, and a refractive index (RI) detector (RID-10A, Shimadzu, Columbia, MD). The separation was run at $85^{\circ} \mathrm{C}$ with a sample injection volume of $25 \mu \mathrm{L}$ and $18 \mathrm{mQ}$ NANOpure water as a mobile phase at a flow rate of $0.6 \mathrm{ml} \cdot \mathrm{min}^{-1}$. The aqueous solutions, containing glucose, xylose, galactose, arabinose, mannose, fructose and sucrose at four concentration levels, were used to create standard curves to quantify the sugar content in the sample. Organic acid and alcohol concentrations in supernatants were determined using an Aminex HPX-87H column (Bio-Rad Laboratories; Hercules, CA) with the HPLC system (Shimadzu, Columbia, MD) equipped with microguard column, a refractive index (RI) and photodiode array (PDA) detectors (SPD-M20A, Shimadzu, Columbia, MD). The HPLC analysis was run at $60^{\circ} \mathrm{C}$ using $5 \mathrm{mM} \mathrm{H}_{2} \mathrm{SO}_{4}$ in $18 \mathrm{mQ}$ NANOpure water as a mobile phase at a flow rate of $0.6 \mathrm{ml} \cdot \mathrm{min}^{-1}$ to elute the sample injected at a volume of $25 \mu \mathrm{L}$. The aqueous solutions, containing galacturonic acid, lactic acid, formic acid, acetic acid and ethanol at four concentration levels, were used to create standard curves to quantify the acid contents in the sample.

\subsection{Enzyme Activity Assays}

Cellic CTec2 (cellulase) and Cellic HTec2 (xylanase) enzymes were provided by Novozymes North America, Inc (Franklinton, NC). Pectinex Ultra SPL (P2611) (pectinase) was purchased from Sigma Aldrich, Inc. Representative cellulase, xylanase, and pectinase activities of each enzyme product (Cellic CTec2, Cellic HTec2 and Pectinex Ultra SPL) were determined using a method described by Ghose and Bisaria [26] [27]. The corresponding activity units were reported as a filter paper unit (FPU), a xylanase unit (XU) and a polygalacturonase unit (PGU), respectively.

\subsection{Enzymatic Hydrolysis}

Enzymatic hydrolysis of sugar beet leaves was performed 100-ml Erlenmeyer flasks at $10 \% \mathrm{w} / \mathrm{v}$ total solids loading by mixing ground biomass with sodium citrate buffer ( $\mathrm{pH} 4.8$ ) to obtain a final concentration of $0.05 \mathrm{M}$ in total working mass of $50 \mathrm{~g}$. Penicillin $\left(20 \mathrm{mg} \cdot \mathrm{l}^{-1}\right)$ and sodium azide $(0.2 \% \mathrm{w} / \mathrm{v})$ were added to the mixture to prevent microbial contamination. Preliminary studies on the effect of antibiotic addition showed that penicillin and sodium azide are needed for the inhibition of microbial contamination and growth. Enzymes (CTec2, HTec2 and Pectinex Ultra SPL) were added to the mixture at concentrations according to the experimental design (Table 1). Hydrolyses were performed at $50^{\circ} \mathrm{C}$ and the flasks shaken at $150 \mathrm{rpm}$ for $72 \mathrm{~h}$. Samples $(2 \mathrm{ml})$ were taken every $24 \mathrm{~h}$ from each flask, diluted (5 times) with deionized water, and immediately centrifuged at $8000 \mathrm{rpm}$ for $15 \mathrm{~min}$ at $4^{\circ} \mathrm{C}$ (HeraeusMultifuge X1R centrifuge, 
Table 1. Experimental design for response surface methodology model, and summary of results for sugar conversion from enzyme hydrolysis of sugar beet leaves at $24 \mathrm{~h}, 48 \mathrm{~h}$ and $72 \mathrm{~h}$.

\begin{tabular}{|c|c|c|c|c|c|c|}
\hline \multirow{2}{*}{ Run } & \multirow{2}{*}{$\begin{array}{c}\text { Cellulase } \\
\text { (FPU g }{ }^{-1} \text { glucan) }\end{array}$} & \multirow{2}{*}{$\begin{array}{c}\text { Xylanase } \\
\text { (XU g }{ }^{-1} \text { xylan) }\end{array}$} & \multirow{2}{*}{$\begin{array}{c}\text { Pectinase } \\
\left(\mathrm{PGU} \mathrm{g}^{-1} \mathrm{PGA}^{\mathrm{a}}\right)\end{array}$} & \multicolumn{3}{|c|}{ Sugar conversion (\% Hydrolysis) } \\
\hline & & & & $24 \mathrm{~h}$ & $48 \mathrm{~h}$ & $72 \mathrm{~h}$ \\
\hline 1 & 3 & 1000 & 100 & 59 & 70 & 74 \\
\hline 2 & 10 & 500 & 50 & 60 & 68 & 76 \\
\hline 3 & 10 & 500 & 150 & 64 & 75 & 76 \\
\hline 4 & 10 & 1500 & 50 & 60 & 71 & 75 \\
\hline 5 & 10 & 1500 & 150 & 66 & 75 & 81 \\
\hline 6 & 20 & 159 & 100 & 65 & 77 & 80 \\
\hline 7 & 20 & 1000 & 16 & 61 & 69 & 74 \\
\hline 8 & 20 & 1000 & 100 & 65 & 74 & 78 \\
\hline 9 & 20 & 1000 & 100 & 63 & 72 & 79 \\
\hline 10 & 20 & 1000 & 100 & 66 & 73 & 77 \\
\hline 11 & 20 & 1000 & 100 & 65 & 74 & 79 \\
\hline 12 & 20 & 1000 & 100 & 68 & 76 & 80 \\
\hline 13 & 20 & 1000 & 100 & 67 & 76 & 78 \\
\hline 14 & 20 & 1000 & 184 & 69 & 78 & 81 \\
\hline 15 & 20 & 1841 & 100 & 66 & 76 & 78 \\
\hline 16 & 30 & 500 & 50 & 64 & 72 & 77 \\
\hline 17 & 30 & 500 & 150 & 70 & 80 & 82 \\
\hline 18 & 30 & 1500 & 50 & 68 & 76 & 80 \\
\hline 19 & 30 & 1500 & 150 & 69 & 81 & 81 \\
\hline 20 & 37 & 1000 & 100 & 67 & 78 & 82 \\
\hline
\end{tabular}

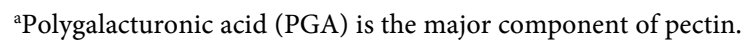

VWR International, Brisbane, CA). After centrifugation, part of the supernatant was stored at $-20^{\circ} \mathrm{C}$ until analysed for nitrogen and protein. The remaining supernatant was immediately filtered through a $0.2-\mu \mathrm{m}$ membrane filter and stored at $-20^{\circ} \mathrm{C}$ for later sugar and acid analyses using HPLC. As shown in Equation (1), sugar conversion was calculated as a percent of the theoretical yield, which was estimated from the total potential monomeric sugar present in the leaves. Total amount of sugar released was analysed after enzymatic hydrolysis, includes galacturonic acid, which is a sugar acid produced from the hydrolysis of pectin. Total sugar content in the biomass was estimated from the compositional results.

$$
\begin{aligned}
& \text { Sugar conversion }(\% \text { hydrolysis }) \\
& =\frac{\text { Total amount of sugar released }(\mathrm{g})}{\text { Total sugar content in the biomass }(\mathrm{g})} \times 100
\end{aligned}
$$




\subsection{Protein Measurement}

Total nitrogen content for the biomass and hydrolyzed samples, before and after three days of hydrolysis, were determined using the Persulfate Digestion Method [28] and a Hach DR 2700 spectrophotometer (Hach Company, Loveland, CO). The protein content was estimated from the multiplication of the nitrogen content by 6.25. Solubilized protein content was determined using the standard Bradford protein assay [29]. Bovine serum albumin (BSA) at four concentration levels was used as a standard for calibration. To exclude the protein from the enzyme addition, the protein content of enzyme controls was used to subtract the protein content from enzymatic hydrolysates.

\subsection{Experimental Design and Statistical Analysis}

Response surface methodology (RSM) was used to optimize the enzymatic hydrolysis of beet leaves at 10\% TS loading using an enzyme mix of CTec2, HTec2 and Pectinex Ultra SPL. A three-factor rotatable central composite design (CCD) was used for determination of the effects and interactions of cellulase, xylanase and pectinase on the enzymatic hydrolysis. Enzyme loadings were the variable parameters in a range of $10-30 \mathrm{FPU} \mathrm{g}^{-1}$ glucan, $500-1500 \mathrm{XU} \mathrm{g}^{-1}$ xylan, and 50 - 150 PGU g ${ }^{-1}$ polygalacturonic acid for cellulase, xylanase, and pectinase respectively. Sugar conversion after $24 \mathrm{~h}, 48 \mathrm{~h}$ and $72 \mathrm{~h}$ of hydrolysis were used as response variables. Each of the enzyme loadings was studied at five levels with six replicates at the center point. A total of 20 experiments were performed, as shown in Table 1. A quadratic polynomial equation was fitted for evaluation of the mathematical relationship between the variables and response. Analysis of variance (ANOVA) was used for the estimation of the statistical parameters, using JMP Pro 10 statistical software (SAS Institute Inc.; Cary, NC).

\section{Results and Discussion}

\subsection{Composition of Sugar Beet Leaves}

Solids analysis results for sugar beet leaves show that the percentages of TS, VS, and VS/TS are $14.20 \% \pm 0.05 \% \mathrm{wb}, 11.35 \% \pm 0.06 \% \mathrm{wb}$, and $79.92 \% \pm 0.06 \% \mathrm{db}$, respectively. The chemical compositional data for the beet leaves are shown in Table 2. On a dry basis, sugar beet leaves are mainly composed of structural carbohydrates (32.4\%), protein (26.9\%), and soluble sugars (10.0\%). The structural carbohydrates are composed of polymeric sugars in nearly equal amounts of glucan (11.0\%), hemicellulosic-derived sugars (xylan, galactan, and arabinan) (10.4\%), and polygalacturonic acid (11.0\%).

To use sugar beet leaves as a feedstock for biofuel production, it is important to access and utilize structural carbohydrates, as they are vital carbon sources. Enzymatic hydrolysis is crucial for depolymerizing structural components to soluble sugars, and for liquefying feedstock at high solids loadings to improve mixing and pumping.

As present in a considerable amount, galacturonic acid a pectin-derived sugar-acid is also a major carbon source. The fermentation of galacturonic acid can 
Table 2. The composition of sugar beet leaves on a dry basis (\% of DB).

\begin{tabular}{cc}
\hline Biomass component & $\%$ DB \\
\hline Structural Carbohydrates & $32.4 \pm 0.26$ \\
Glucan & $11.0 \pm 0.10$ \\
Xylan & $2.4 \pm 0.05$ \\
Galactan & $3.0 \pm 0.05$ \\
Arabinan & $5.0 \pm 0.06$ \\
Polygalacturonic acid & $11.0 \pm 0.06$ \\
Soluble Sugars & $10.0 \pm 2.32$ \\
Glucose & $7.0 \pm 2.09$ \\
Fructose & $1.6 \pm 0.40$ \\
Sucrose & $1.4 \pm 0.32$ \\
Protein & $26.9 \pm 0.94$ \\
Lignin & $6.2 \pm 0.17$ \\
Ash & $19.6 \pm 1.47$ \\
\hline
\end{tabular}

increase ethanol yield significantly. Although wild type Saccaromycescerevisea cannot ferment these substrates to ethanol, many novel microorganisms have been researched and metabolically engineered for the ethanolic fermentation of pectin [30]-[35]. A novel metabolic pathway from Escherichia coli KO11 was developed to allow the fermentation of galacturonic acid to equal molar amount of ethanol and acetate [32] [33]. In addition, Clostridium species (C. phytofermentans [36] [37] and C. cellulyticum [38]) and ethanologenic constructed bacteria in genus Erwinia (E. chrysanthemi EC16 and E. carotovora SR38 [34]) showed potential for the direct hydrolysis and fermentation of pectin to ethanol. The use of these microorganisms would make the overall ethanol production from pectin-rich biomass, such as sugar beet leaves, more economically feasible.

\subsection{Enzyme Activity}

Results from the enzyme activity assays conducted are shown in Table 3. Filter paper, xylanase, and polygalacturonase assays were conducted for the representative measurement of these enzyme activities, acknowledging that these are not a full description of all enzyme activities that may be present. The primary specific activities of Cellic CTec2 (cellulase), Cellic HTec2 (xylanase) and Pectinex Ultra SPL (pectinase) are $125 \mathrm{FPU} \mathrm{ml}^{-1}, 9685 \mathrm{XU} \mathrm{ml}^{-1}$, and $9848 \mathrm{PGU} \mathrm{ml}^{-1}$, respectively. Most commercial enzyme products are a mixture of various enzyme types, and thus they can catalyze several reactions. CTec2 was found to exhibit relatively high xylanase activity, with $4261 \mathrm{XU} \mathrm{ml}^{-1}$. However, for the experimental design, enzyme loading is determined based on the primary specific activity of each enzyme. 
The enzymes used in this experiment have been studied and reported on in other research works [39] [40] [41] [42]. The enzyme activities determined in this experiment are in the same range as those reported previously, as shown in Table 4. The xylanase activities for Cellic HTec that can be found in previous studies range from 1090 to $10,596 \mathrm{XU} \mathrm{m}^{-1}$ [40] [41] [42]. Such a range might be attributable to the sensitivity of the activity measurement (due to the lack of linearity between enzyme concentration and product liberation) and the accuracy of the measurement since the measurement of xylanase activity is complex [26].

\subsection{Optimization of Sugar Conversion from Sugar Beet Leaves}

\subsubsection{Degree of Hydrolysis and Sugar Conversions}

The designed enzyme loadings and the corresponding results for enzymatic hydrolysis of sugar beet leaves for $24 \mathrm{~h}, 48 \mathrm{~h}$ and $72 \mathrm{~h}$ are shown in Table 1 . The degree of enzymatic hydrolysis is in the range of $59 \%-70 \%, 68 \%-80 \%$, and $74 \%-82 \%$ for $24 \mathrm{~h}, 48 \mathrm{~h}$ and $72 \mathrm{~h}$ of hydrolysis, respectively. The degree of hydrolysis depends on the enzyme mixture and loadings, with the maximum sugar conversion achieved after $72 \mathrm{~h}$ of hydrolysis as $82 \%$.

Table 3. Enzyme activities of cellulase, xylanase and pectinase used in the experiment.

\begin{tabular}{cccc}
\hline \multirow{3}{*}{ Enzyme Product } & \multicolumn{3}{c}{ Enzyme Activity $^{\mathrm{a}}$} \\
\cline { 2 - 4 } & $\begin{array}{c}\text { Cellulase } \\
\left(\mathrm{FPU} \mathrm{ml}^{-1}\right)\end{array}$ & $\begin{array}{c}\text { Xylanase } \\
\left(\mathrm{XU} \mathrm{ml}^{-1}\right)\end{array}$ & $\begin{array}{c}\text { Pectinase } \\
\left(\mathrm{PGU} \mathrm{ml}^{-1}\right)\end{array}$ \\
\hline Cellic CTec2 & 125 & 4261 & 29 \\
Cellic HTec2 & 41 & 9685 & 16 \\
Pectinex Ultra SPL & 0.2 & 4 & 9848 \\
\hline
\end{tabular}

a One enzyme unit $(U)$ is defined as the amount of the enzyme that catalyzes the conversion of 1 micromole of substrate per minute.

Table 4. Previous studies on enzyme activities as references [39] [40] [41] [42] [43].

\begin{tabular}{|c|c|c|c|c|c|c|}
\hline \multirow[b]{2}{*}{ Enzyme } & \multicolumn{4}{|c|}{ Activity } & \multirow{2}{*}{$\begin{array}{c}\text { Protein } \\
\text { content } \\
\left(\mathrm{g} \cdot \mathrm{l}^{-1}\right)\end{array}$} & \multirow[b]{2}{*}{ Source } \\
\hline & $\begin{array}{l}\text { Cellulases } \\
\left(\mathrm{FPU} \mathrm{ml} \mathrm{m}^{-1}\right)\end{array}$ & $\begin{array}{l}\text { Xylanase } \\
\left(\mathrm{XU} \mathrm{m} \mathrm{m}^{-1}\right)\end{array}$ & $\begin{array}{l}\text { Pectinase } \\
\left(\text { PGU ml }{ }^{-1}\right)\end{array}$ & $\begin{array}{l}\text { Cellobiase } \\
\left(\mathrm{CBU} \mathrm{ml}^{-1}\right)\end{array}$ & & \\
\hline Cellic CTec2 & 108.3 & & & & 185.2 & {$[40]$} \\
\hline \multirow[t]{3}{*}{ Cellic CTec } & $106-130$ & $169-206^{a}$ & & $1000-1223$ & 193.3 & [39] \\
\hline & 115.6 & & & & & [42] \\
\hline & 86.5 & & & 575 & 141.2 & [40] \\
\hline \multirow[t]{3}{*}{ Cellic HTec } & & 10,596 & & & & {$[41]$} \\
\hline & & 1090 & & & & {$[42]$} \\
\hline & & 1090 & & & 34.4 & {$[40]$} \\
\hline $\begin{array}{l}\text { Pectinex } \\
\text { Ultra SPL }\end{array}$ & & & 9500 & & & [43] \\
\hline
\end{tabular}

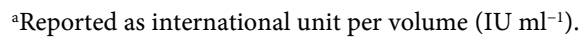


Enzymatic hydrolysis produced a significantly higher sugar conversion than the non-enzyme control. Compared to the initial sugar release at time zero, enzymatic hydrolysis increases sugar release an average of 51\% (40\%-63\%), 74\% $(60 \%-84 \%)$, and $84 \%(70 \%-100 \%)$ after $24 \mathrm{~h}, 48 \mathrm{~h}$, and $72 \mathrm{~h}$, respectively. In contrast, after 24 to $72 \mathrm{~h}$ of hydrolysis without enzyme addition, only $15 \%-26 \%$ of sugars are released. The maximum sugar yield from the enzyme hydrolysis were $0.30,0.34$, and $0.35 \mathrm{~g}$ sugar $\mathrm{g}^{-1} \mathrm{TS}$ after 24,48 , and $72 \mathrm{~h}$, respectively. The maximum sugar concentrations were 30,34 , and $35 \mathrm{~g} \cdot \mathrm{l}^{-1}$ after 24,48 , and $72 \mathrm{~h}$, respectively.

Increases in the enzyme loadings of cellulase and/or pectinase result in increases in the sugar conversion at all xylanase loadings. Cellulase and pectinase loadings needed to be greater than $10 \mathrm{FPU} \mathrm{g}^{-1}$ glucan or $50 \mathrm{PGU} \mathrm{g} \mathrm{g}^{-1}$ polygalacturonic acid to achieve sugar conversion greater than $80 \%$ after $72 \mathrm{~h}$ of hydrolysis. A decrease in any single enzyme loading can be partially offset by an increase in another as described in the following section.

\subsubsection{ANOVA Results}

The significance of regression models for total sugar conversion from enzymatic hydrolysis of sugar beet leaves were tested by $F$-test and analysis of variance (ANOVA). ANOVA results for the sugar conversion models for $24 \mathrm{~h}, 48 \mathrm{~h}$, and $72 \mathrm{~h}$ hydrolysis are listed in Table 5. The regression models with full RSM are significant at the $95 \%$ confidence interval, with the $p$-values $0.002,0.000$ and 0.027 for 24,48 and $72 \mathrm{~h}$ of hydrolysis, respectively.

All models passed the lack of fit test ( $p=0.763$ for $24 \mathrm{~h}, p=0.789$ for $48 \mathrm{~h}$, and $p=0.074$ for $72 \mathrm{~h}$ of hydrolysis), indicating model adequacy. Although all models are shown to be adequate, the models for 24 and $48 \mathrm{~h}\left(\mathrm{R}^{2}=0.877\right.$ and $\mathrm{R}_{\text {adj }}^{2}=0.767$ for $24 \mathrm{~h}$ and $\mathrm{R}^{2}=0.919$ and $\mathrm{R}_{\text {adj }}^{2}=0.847$ for $48 \mathrm{~h}$ ) are stronger than is the model for $72 \mathrm{~h}$ hydrolysis $\left(\mathrm{R}^{2}=0.768\right.$ and $\left.\mathrm{R}_{\text {adj }}^{2}=0.559\right)$. The relative strength of the $48 \mathrm{~h}$ model might be attributable to the fact that most of sugars were released at $48 \mathrm{~h}$ of hydrolysis. After $72 \mathrm{~h}$ of hydrolysis, enzymatic reactions were almost complete and each enzyme loading was reaching the same sugar conversion; thus, the conversion model is less dependent on different enzyme loadings.

\subsubsection{Regression Models}

Regression models for total sugar conversion from enzymatic hydrolysis of sugar beet leaves, disregarding factors with $p>0.05$ from the full response surface model, for $24 \mathrm{~h}, 48 \mathrm{~h}$, and $72 \mathrm{~h}$ are represented by Equations (2)-(4), respectively. The response variable $(\mathrm{R})$ is sugar conversion as the percentage hydrolysis of the total sugars in sugar beet leaves.

Sugar conversion from the hydrolysis of sugar beet leaves demonstrates linear relationships with cellulase $(\mathrm{C})$ and pectinase $(\mathrm{P})$ loadings for all time points. The significance $(p<0.05)$ of the coefficients for the regression models for sugar conversion is shown in Table 6. Both cellulase and pectinase linear terms show high significance $(p<0.01)$ for all three days of hydrolysis. The effects for xylanase 
Table 5. Results from Analysis of Variance (ANOVA) with full RSM model.

\begin{tabular}{|c|c|c|c|c|c|}
\hline Source of Variation & $\begin{array}{l}\text { Degree of } \\
\text { freedom }\end{array}$ & $\begin{array}{l}\text { Sum of } \\
\text { squares }\end{array}$ & $\begin{array}{l}\text { Mean } \\
\text { Square }\end{array}$ & F-value & $p$-value \\
\hline \multicolumn{6}{|l|}{ For $24 \mathrm{~h}$} \\
\hline Regression Model & 9 & 170.03 & 18.89 & 7.95 & 0.002 \\
\hline Residual & 10 & 23.77 & 2.38 & & \\
\hline Total & 19 & 193.80 & & & \\
\hline Lack of fit & 5 & 8.44 & 1.69 & 0.55 & 0.736 \\
\hline Pure Error & 5 & 15.33 & 3.07 & & \\
\hline Summary of fit & $\mathrm{R}^{2}=0.877$ & $\mathrm{R}_{\mathrm{adj}}^{2}=0.767$ & & & \\
\hline \multicolumn{6}{|l|}{ For $48 \mathrm{~h}$} \\
\hline Regression Model & 9 & 214.13 & 23.79 & 12.64 & 0.000 \\
\hline Residual & 10 & 18.82 & 1.88 & & \\
\hline Total & 19 & 232.95 & & & \\
\hline Lack of fit & 5 & 5.98 & 1.20 & 0.47 & 0.789 \\
\hline Pure Error & 5 & 12.83 & 2.57 & & \\
\hline Summary of fit & $\mathrm{R}^{2}=0.919$ & $\mathrm{R}_{\mathrm{adj}}^{2}=0.847$ & & & \\
\hline \multicolumn{6}{|l|}{ For $72 \mathrm{~h}$} \\
\hline Regression Model & 9 & 92.73 & 10.30 & 3.67 & 0.027 \\
\hline Residual & 10 & 28.07 & 2.81 & & \\
\hline Total & 19 & 120.80 & & & \\
\hline Lack of fit & 5 & 22.57 & 4.51 & 4.10 & 0.074 \\
\hline Pure Error & 5 & 5.50 & 1.10 & & \\
\hline Summary of fit & $\mathrm{R}^{2}=0.768$ & $\mathrm{R}_{\mathrm{adj}}^{2}=0.559$ & & & \\
\hline
\end{tabular}

Table 6. Significance of coefficients in the sugar conversion full RSM models for the enzymatic hydrolysis of sugar beet leaves.

\begin{tabular}{ccccccccccc}
\hline \multirow{2}{*}{$\begin{array}{c}\text { Hydrolysis } \\
\text { Time (h) }\end{array}$} & \multicolumn{7}{c}{ Significance of model terms $(p$-value $)$} \\
\cline { 2 - 10 } & $\mathrm{C}^{\mathrm{a}}$ & $\mathrm{H}^{\mathrm{a}}$ & $\mathrm{P}^{\mathrm{a}}$ & $\mathrm{CH}$ & $\mathrm{CP}$ & $\mathrm{HP}$ & $\mathrm{C}^{2}$ & $\mathrm{H}^{2}$ & $\mathrm{P}^{2}$ \\
\hline 24 & 0.0001 & 0.268 & 0.0001 & 0.823 & 0.507 & 0.507 & 0.079 & 0.833 & 0.831 \\
48 & $<0.0001$ & 0.241 & $<0.0001$ & 0.617 & 0.617 & 0.153 & 0.898 & 0.043 & 0.548 \\
72 & 0.002 & 0.679 & 0.003 & 0.682 & 1.000 & 0.682 & 0.822 & 0.582 & 0.542 \\
\hline
\end{tabular}

${ }^{\mathrm{a}} \mathrm{C}$ : cellulase, $\mathrm{H}$ : xylanase, $\mathrm{P}$ : pectinase..

and all quadratic and interaction terms are not significant, except at $48 \mathrm{~h}$ of hydrolysis when the quadratic term for xylanase appears to be significant with $95 \%$ confidence interval $(p=0.043)$.

Regression Models: 


$$
\begin{gathered}
R=65.64+2.523(C)+2.230(P) \\
R=74.16+2.450(C)+2.866(P)+0.836\left(H^{2}\right) \\
R=78.49+1.864(C)+1.741(P)
\end{gathered}
$$

\subsubsection{Relationship between Enzyme Loadings and Sugar Conversion}

The relationships between the enzyme loadings and sugar conversion produced from 24,48 , and $72 \mathrm{~h}$ of hydrolysis are shown in the two-dimensional contour plots in Figure 1(a)-(c), respectively. The results show that the trend in the relationship between enzyme loadings and sugar conversion is similar for each model. In correspondence with the regression models, an increase in cellulase and pectinase loadings results in an increase in sugar release. The maximum yields within the design space are approximately $80 \%$ of the theoretical maximum after $72 \mathrm{~h}$ of hydrolysis. The yield would be predicted to reach a maximum of $90 \%$ of the theoretical yield after $72 \mathrm{~h}$ hydrolysis at the maximum loading of
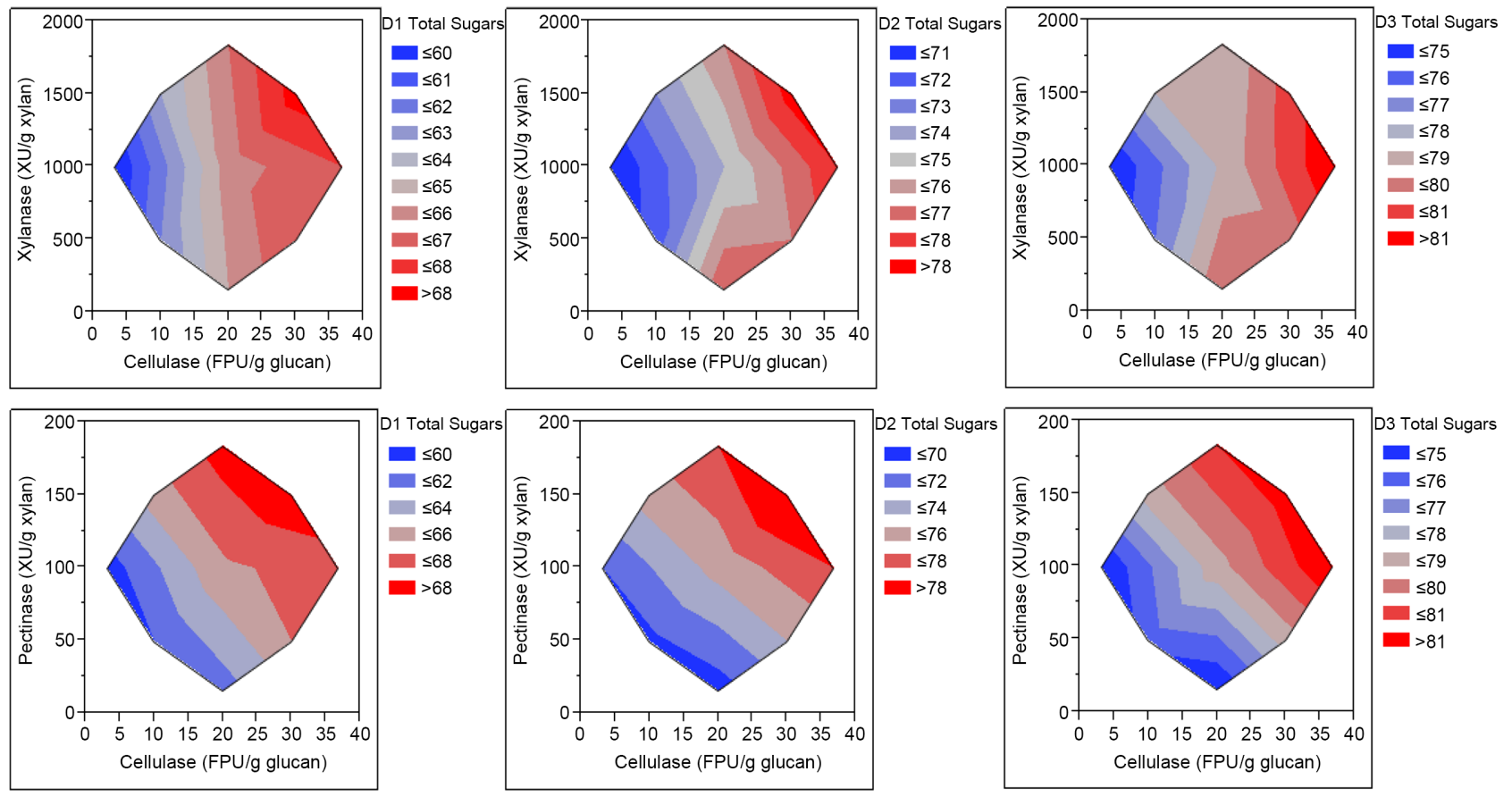

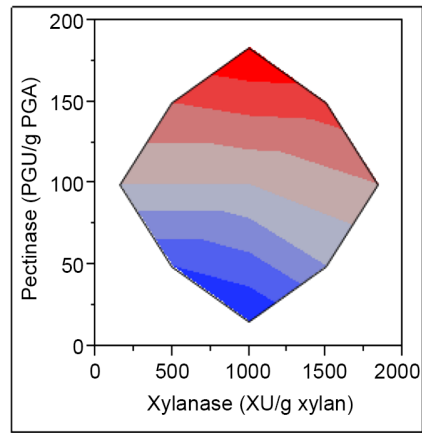

(a)
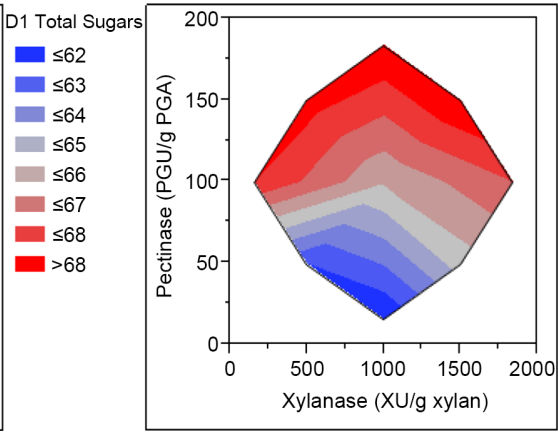

(b)
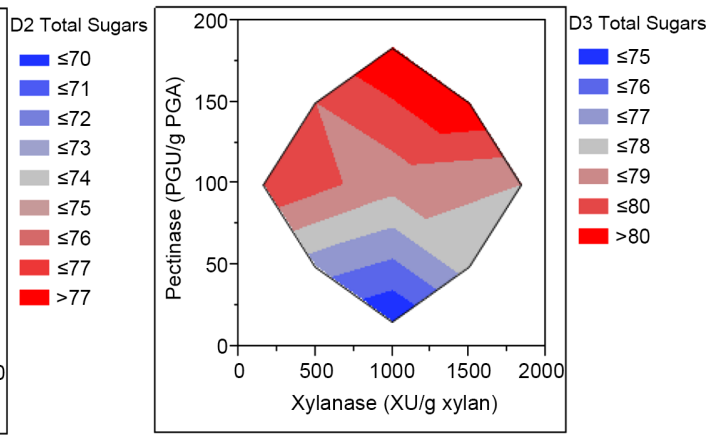

(c)

Figure 1. Contour plot showing the relationship between enzyme loadings and total sugar conversion (\% hydrolysis) from enzymatic hydrolysis of sugar beet leaves for $24 \mathrm{~h}$ (a), $48 \mathrm{~h}(\mathrm{~b})$, and $72 \mathrm{~h}$ (c). 
cellulase and pectinase. As the regression models show the linear terms for cellulase and pectinase are significant, a larger range of enzyme concentrations might need to be further investigated to observe optimum concentration.

Investigation of enzymatic hydrolysis has been studied widely for lignocellulosic biomass using mixtures of the similar enzymes. However, this study presents the enzymatic hydrolysis of sugar beet leaves in a context of biofuel production for the first time. The sugar conversion results are in the same range as those from other enzymatic hydrolysis studies on other leafy biomass [41] [44] [45].

The composition of the biomass is one of the factors that determine the formulation of the enzymes required during hydrolysis process. Cellic HTec2 addition within the design space does not improve sugar release, which may be a result of the small amount of xylan present in the sugar beet leaves and indication from the enzyme producer that Cellic HTec2 has been developed mainly supplement xylanase activity. According to [44], who studied various pretreatments for switchgrass, the addition of xylanase showed a negligible improvement $(0 \%$ $2 \%)$ over the pretreatments (dilute-acid and $\mathrm{SO}_{2}$ ) with low xylan-containing biomass. However, higher xylanase loadings in some high xylan-containing biomass showed an increase on glucan release [41] [44]. According to Pryor's study on the enzymatic hydrolysis of switchgrass pretreated through an aqueous ammonia soaking, the process required the xylanase addition of $3900 \mathrm{XU} \mathrm{g}^{-1}$ glucan with a cellulase minimum of $19 \mathrm{FPU} \mathrm{g}^{-1}$ glucan in order to reach $85 \%$ glucan yield [41].

\subsection{Protein Recovery}

Soluble proteins released from the biomass after $72 \mathrm{~h}$ of enzymatic hydrolysis ranged from $59 \%$ to $68 \%$ (an average of $62.8 \% \pm 3.0 \%$ ) of total protein, comparing to $52 \%$ of total protein released from hydrolysis without enzyme addition. To exclude the protein from the enzyme addition, the protein content in the hydrolysate was subtracted by those in the enzyme controls. From the selected range of enzyme loadings, the statistical analysis (significance of regression models and ANOVA) shows that the type of enzymes, enzyme loadings, and the interaction and polynomial terms are not significant $(p<0.05)$ in relation to solubilized protein. The protein remaining in the biomass after $72 \mathrm{~h}$ of hydrolysis is approximately $37.2 \% \pm 3.0 \%$ of total protein. The insoluble protein could be potentially separated from the hydrolysate and used as nitrogen supplement or in protein meals.

The high protein content of sugar beet leaves would provide sufficient nitrogen for microbial requirement during a sequential fermentation process [46]. In addition to carbon sources for biofuel conversion, nutrients are essential for microbial growth and maintenance during the fermentation. Nitrogen is a major cellular component of microorganisms. The amount of nitrogen required for biomass synthesis can be estimated from the empirical formula for a bacterial cell as $\mathrm{C}_{5} \mathrm{H}_{7} \mathrm{O}_{2} \mathrm{~N}$ [47]. Previous studies on the effect of nitrogen on ethanol fer- 
mentation have shown the adverse effects of nitrogen deficiency [48] [49] [50]. The lack of nitrogen diminishes yeast's metabolic activity, sugar uptake rate, and the cell biomass during fermentation.

Excess nitrogen from sugar beet leaves after fermentation can be recovered as amino acid supplements, nitrogen source, or fertilizer. Nitrogen fertilizer can be recovered from biomass residues after biofuel production, potentially through anaerobic digestion. Recovering nitrogen as fertilizer helps reduce large nitrogen consumption during plant biomass cultivation, and thus improves soil quality and the cost for fertilizer usage. The co-production of fertilizer products also helps improve the overall economic of the biofuel production system.

\section{Conclusion}

Cellulase (Cellic CTec2) and pectinase (Pectinex Ultra SPL) were found to be important enzymes for hydrolysis of sugarbeet leaves at a high solids loading (10\% TS), likely due to the high glucan and polygalacturonic acid contents of the biomass. Enzyme hydrolysis for $48 \mathrm{~h}$ at the enzyme loading of $30 \mathrm{FPU} \mathrm{g}^{-1}$ glucan for cellulase and $150 \mathrm{PGU} \mathrm{g}^{-1}$ polygalacturonic acid for pectinase appeared optimal as it allowed for maximum sugar conversion up to $80 \%$. In contrast, increasing the enzyme loadings had no significant impact on protein release although enzyme addition provided an increase in the recovery of soluble protein. The regression model developed in this study provided an estimation of sugar conversion from the hydrolysis of sugar beet leaves, which is potentially used for designing a biorefinery process of leafy biomass. However, the model estimation might be limited to biomass feedstocks with similar composition, and the use of enzyme loadings within the range studied.

\section{Acknowledgements}

This research was supported with grant from California Energy Commission and Mendota Bioenergy, LLC. The authors would like to thank the Strategic Scholarships for Frontier Research Network Program funded by the Royal Thai Government for the financial support, and the University of California, Davis for providing the funding and research facility.

\section{References}

[1] Mussatto, S.I., Dragone, G., Guimarães, P.M.R., Silva, J.P.A., Carneiro, L.M., Roberto, I.C., Vicente, A., Domingues, L. and Teixeira, J.A. (2010) Technological Trends, Global Market, and Challenges of Bio-Ethanol Production. Biotechnology Advances, 28, 817-830. https://doi.org/10.1016/j.biotechadv.2010.07.001

[2] Singh, P., Suman, A., Tiwari, P., Arya, N., Gaur, A. and Shrivastava, A.K. (2008) Biological Pretreatment of Sugarcane Trash for Its Conversion to Fermentable Sugars. World Journal of Microbiology and Biotechnology, 24, 667-673. https://doi.org/10.1007/s11274-007-9522-4

[3] Krishnan, C., Sousa, L.D.C., Jin, M., Chang, L., Dale, B.E. and Balan, V. (2010) Alkali-Based AFEX Pretreatment for the Conversion of Sugarcane Bagasse and Cane Leaf Residues to Ethanol. Biotechnology and Bioengineering, 107, 441-450. https://doi.org/10.1002/bit.22824 
[4] Pandey, A., Soccol, C.R., Nigam, P. and Soccol, V.T. (2000) Biotechnological Potential of Agro-Industrial Residues. I: Sugarcane Bagasse. Bioresource Technology, 74, 69-80. https://doi.org/10.1016/S0960-8524(99)00142-X

[5] Chandel, A.K., da Silva, S.S., Carvalho, W. and Singh, O.V. (2012) Sugarcane Bagasse and Leaves: Foreseeable Biomass of Biofuel and Bio-Products. Journal of Chemical Technology and Biotechnology, 87, 11-20.

https://doi.org/10.1002/jctb.2742

[6] Dale, B.E., Allen, M.S., Laser, M. and Lynd, L.R. (2009) Protein Feeds Coproduction in Biomass Conversion to Fuels and Chemicals. Biofuels, Bioproducts and Biorefining, 3, 219-230. https://doi.org/10.1002/bbb.132

[7] Carlsson, R. and Hanczakowski, P. (1989) Waste Green Parts of Plants as Raw Material For Leaf Protein Concentrate Production. Biological Wastes, 28, 83-90.

https://doi.org/10.1016/0269-7483(89)90072-4

[8] Jwanny, E.W., Montanari, L. and Fantozzi, P. (1993) Protein Production for Human Use from Sugarbeet: Byproducts. Bioresource Technology, 43, 67-70. https://doi.org/10.1016/0960-8524(93)90085-P

[9] USDA (2012) National Statistics for Sugarbeets-Production and Yield. National Agricultural Statistics Service.

[10] Salazar-Ordóñez, M., Pérez-Hernández, P.P. and Martín-Lozano, J.M. (2013) Sugar Beet for Bioethanol Production: An Approach Based on Environmental Agricultural Outputs. Energy Policy, 55, 662-668. https://doi.org/10.1016/j.enpol.2012.12.063

[11] Holcomb, R. (2013) Agricultural Statistics 2012. US Department of Agriculture, National Agricultural Statistics Service (NASS), 549.

[12] Moutta, R.O., Chandel, A.K., Rodrigues, R., Silva, M.B., Rocha, G.J.M. and Silva, S.S. (2012) Statistical Optimization of Sugarcane Leaves Hydrolysis into Simple Sugars by Dilute Sulfuric Acid Catalyzed Process. Sugar Tech, 14, 53-60. https://doi.org/10.1007/s12355-011-0116-y

[13] Browne, C.A. and Blouin, R. (1907) The Chemistry of the Sugar Cane and Its Products in Louisiana. Agricultural Experiment Station, Baton Rouge.

[14] Da Silva, A.S.A., Inoue, H., Endo, T., Yano, S. and Bon, E.P.S. (2010) Milling Pretreatment of Sugarcane Bagasse and Straw for Enzymatic Hydrolysis and Ethanol Fermentation. Bioresource Technology, 101, 7402-7409.

https://doi.org/10.1016/j.biortech.2010.05.008

[15] Ferreira-Leitao, V., Perrone, C., Rodrigues, J., Franke, A., Macrelli, S. and Zacchi, G. (2010) An Approach to the Utilisation of $\mathrm{CO}_{2}$ as Impregnating Agent in Steam Pretreatment of Sugar Cane Bagasse and Leaves for Ethanol Production. Biotechnology for Biofuels, 3, 7. https://doi.org/10.1186/1754-6834-3-7

[16] Chen, J., Liang, R., Liu, W., Luo, S., Liu, C., Wu, S. and Wang, Z. (2014) Extraction of Pectin from Premna microphylla Turcz Leaves and Its Physicochemical Properties. Carbohydrate Polymers, 102, 376-384.

https://doi.org/10.1016/j.carbpol.2013.11.069

[17] Dien, B.S., Jung, H.-J.G., Vogel, K.P., Casler, M.D., Lamb, J.F.S., Iten, L., Mitchell, R.B. and Sarath, G. (2006) Chemical Composition and Response to Dilute-Acid Pretreatment and Enzymatic Saccharification of Alfalfa, Reed Canarygrass, and Switchgrass. Biomass and Bioenergy, 30, 880-891. https://doi.org/10.1016/j.biombioe.2006.02.004

[18] Johnson, J.M.-F., Barbour, N.W. and Weyers, S.L. (2007) Chemical Composition of Crop Biomass Impacts Its Decomposition. Soil Science Society of America Journal, 71, 155-162. https://doi.org/10.2136/sssaj2005.0419 
[19] Rule, D.C., Koch, D.W., Jones, R.R. and Kercher, C.J. (1991) Brassica and Sugarbeet Forages for Lambs-Growth Performance of Lambs and Composition of Forage and Dock-Fat Fatty Acids. Journal of Production Agriculture, 4, 29-33. https://doi.org/10.2134/jpa1991.0029

[20] Aufrère, J. and Michalet-Doreau, B. (1988) Comparison of Methods for Predicting Digestibility of Feeds. Animal Feed Science and Technology, 20, 203-218. https://doi.org/10.1016/0377-8401(88)90044-2

[21] Draycott, A.P. (2006) Sugar Beet. Wiley, Oxford. https://doi.org/10.1002/9780470751114

[22] Spagnuolo, M., Crecchio, C., Pizzigallo, M.D.R. and Ruggiero, P. (1997) Synergistic Effects of Cellulolytic and Pectinolytic Enzymes in Degrading Sugar Beet Pulp. Bioresource Technology, 60, 215-222. https://doi.org/10.1016/S0960-8524(97)00013-8

[23] Edwards, M.C. and Doran-Peterson, J. (2012) Pectin-Rich Biomass as Feedstock for Fuel Ethanol Production. Applied Microbiology and Biotechnology, 95, 565-575. https://doi.org/10.1007/s00253-012-4173-2

[24] Sluiter, A., Hames, B., Ruiz, R., Scarlata, C., Sluiter, J., Templeton, D. and Crocker, D. (2008) Determination of Structural Carbohydrates and Lignin in Biomass. National Renewable Energy Laboratory Analytical Procedure, Golden.

[25] Sluiter, A., Ruiz, R., Scarlata, C., Sluiter, J. and Templeton, D. (2005) Determination of Extractives in Biomass. National Renewable Energy Laboratory Analytical Procedure, Golden.

[26] Ghose, T. and Bisaria, V.S. (1987) Measurement of Hemicellulase Activities. Part 1: Xylanases. Pure and Applied Chemistry, 59, 1739-1752. https://doi.org/10.1351/pac198759121739

[27] Ghose, T. (1987) Measurement of Cellulase Activities. Pure and Applied Chemistry, 59, 257-268. https://doi.org/10.1351/pac198759020257

[28] Hach (2012) Nitrogen, Total, Persulfate Digestion HR Method 10072, Test 'N Tube Vials. 7th Edition, Hach Company, Loveland.

[29] Bradford, M.M. (1976) A Rapid and Sensitive Method for the Quantitation of Microgram Quantities of Protein Utilizing the Principle of Protein-Dye Binding. Analytical Biochemistry, 72, 248-254. https://doi.org/10.1016/0003-2697(76)90527-3

[30] Doran, J., Cripe, J., Sutton, M. and Foster, B. (2000) Fermentations of Pectin-Rich Biomass with Recombinant Bacteria to Produce Fuel Ethanol. Applied Biochemistry and Biotechnology, 84-86, 141-152. https://doi.org/10.1385/ABAB:84-86:1-9:141

[31] Doran-Peterson, J., Cook, D.M. and Brandon, S.K. (2008) Microbial Conversion of Sugars from Plant Biomass to Lactic Acid or Ethanol. Plant Journal, 54, 582-592. https://doi.org/10.1111/j.1365-313X.2008.03480.x

[32] Grohmann, K., Baldwin, E.A., Buslig, B.S. and Ingram, L.O.N. (1994) Fermentation of Galacturonic Acid and Other Sugars in Orange Peel Hydrolysates by the Ethanologenic Strain of Escherichia coli. Biotechnology Letters, 16, 281-286. https://doi.org/10.1007/BF00134626

[33] Grohmann, K., Cameron, R. and Buslig, B. (1996) Fermentation of Orange Peel Hydrolysates by Ethanologenic Escherichia coli. In: Wyman, C. and Davison, B., Eds., 17 th Symposium on Biotechnology for Fuels and Chemicals, Humana Press, New York, 383-388. https://doi.org/10.1007/978-1-4612-0223-3 34

[34] Grohmann, K., Manthey, J., Cameron, R. and Buslig, B. (1998) Fermentation of Galacturonic Acid and Pectin-Rich Materials to Ethanol by Genetically Modified Strains of Erwinia. Biotechnology Letters, 20, 195-200.

https://doi.org/10.1023/A:1005349112770 
[35] Van Rijssel, M. and Hansen, T.A. (1989) Fermentation of Pectin by a Newly Isolated Clostridium thermosaccharolyticum Strain. FEMS Microbiology Letters, 61, 41-46. https://doi.org/10.1111/j.1574-6968.1989.tb03549.x

[36] Warnick, T.A., Methé, B.A. and Leschine, S.B. (2002) Clostridium phytofermentans sp. nov., a Cellulolytic Mesophile from Forest Soil. International Journal of Systematic and Evolutionary Microbiology, 52, 1155-1160.

https://doi.org/10.1099/00207713-52-4-1155

[37] Lee, S., Warnick, T., Pattathil, S., Alvelo-Maurosa, J., Serapiglia, M., McCormick, H., Brown, V., Young, N., Schnell, D., Smart, L., Hahn, M., Pedersen, J., Leschine, S. and Hazen, S. (2012) Biological Conversion Assay Using Clostridium phytofermentans to Estimate Plant Feedstock Quality. Biotechnology for Biofuels, 5, 5. https://doi.org/10.1186/1754-6834-5-5

[38] Desvaux, M. (2005) Clostridium cellulolyticum: Model Organism of Mesophilic Cellulolytic Clostridia. FEMS Microbiology Reviews, 29, 741-764. https://doi.org/10.1016/j.femsre.2004.11.003

[39] Alvira, P., Negro, M.J. and Ballesteros, M. (2011) Effect of Endoxylanase and Alpha- $L$-Arabinofuranosidase Supplementation on the Enzymatic Hydrolysis of Steam Exploded Wheat Straw. Bioresource Technology, 102, 4552-4558. https://doi.org/10.1016/j.biortech.2010.12.112

[40] Eckard, A.D., Muthukumarappan, K. and Gibbons, W. (2012) Modeling of Pretreatment Condition of Extrusion-Pretreated Prairie Cordgrass and Corn Stover with Poly (Oxyethylen) ${ }_{20}$ Sorbitan Monolaurate. Applied Biochemistry and Biotechnology, 167, 377-393. https://doi.org/10.1007/s12010-012-9698-4

[41] Pryor, S.W., Karki, B. and Nahar, N. (2012) Effect of Hemicellulase Addition during Enzymatic Hydrolysis of Switchgrass Pretreated by Soaking in Aqueous Ammonia. Bioresource Technology, 123, 620-626. https://doi.org/10.1016/j.biortech.2012.07.040

[42] Xu, J., Zhang, X. and Cheng, J.J. (2012) Pretreatment of Corn Stover for Sugar Production with Switchgrass-Derived Black Liquor. Bioresource Technology, 111, 255260. https://doi.org/10.1016/j.biortech.2012.02.006

[43] Novozymes (2007) Product Data Sheet for Pectinex Ultra SP-L. Gusmer Enterprises Inc.

[44] Falls, M., Shi, J., Ebrik, M.A., Redmond, T., Yang, B., Wyman, C.E., Garlock, R., Balan, V., Dale, B.E., Pallapolu, V.R., Lee, Y.Y., Kim, Y., Mosier, N.S., Ladisch, M.R., Hames, B., Thomas, S., Donohoe, B.S., Vinzant, T.B., Elander, R.T., Warner, R.E., Sierra-Ramirez, R. and Holtzapple, M.T. (2011) Investigation of Enzyme Formulation on Pretreated Switchgrass. Bioresource Technology, 102, 11072-11079. https://doi.org/10.1016/j.biortech.2011.03.035

[45] Singh, A. and Bishnoi, N.R. (2012) Enzymatic Hydrolysis Optimization of Microwave Alkali Pretreated Wheat Straw and Ethanol Production by Yeast. Bioresource Technology, 108, 94-101. https://doi.org/10.1016/j.biortech.2011.12.084

[46] Albers, E., Larsson, C., Lidén, G., Niklasson, C. and Gustafsson, L. (1996) Influence of the Nitrogen Source on Saccharomyces cerevisiae Anaerobic Growth and Product Formation. Applied and Environmental Microbiology, 62, 3187-3195.

[47] Speece, R.E. and McCarty, P.L. (1964) Nutrient Requirements and Biological Solids Accumulation in Anaerobic Digestion. Advances in Water Pollution Research, 2, 305-322. https://doi.org/10.1016/B978-1-4832-8391-3.50034-8

[48] Bely, M., Sablayrolles, J.M. and Barre, P. (1990) Automatic Detection of Assimilable Nitrogen Deficiencies during Alcoholic Fermentation in Oenological Conditions. Journal of Fermentation and Bioengineering, 70, 246-252. 
https://doi.org/10.1016/0922-338X(90)90057-4

[49] Thomas, K.C. and Ingledew, W.M. (1990) Fuel Alcohol Production: Effects of Free Amino Nitrogen on Fermentation of Very-High-Gravity Wheat Mashes. Applied and Environmental Microbiology, 56, 2046-2050.

[50] Varela, C., Pizarro, F. and Agosin, E. (2004) Biomass Content Governs Fermentation Rate in Nitrogen-Deficient Wine Musts. Applied and Environmental Microbiology, 70, 3392-3400. https://doi.org/10.1128/AEM.70.6.3392-3400.2004

Submit or recommend next manuscript to SCIRP and we will provide best service for you:

Accepting pre-submission inquiries through Email, Facebook, LinkedIn, Twitter, etc. A wide selection of journals (inclusive of 9 subjects, more than 200 journals) Providing 24-hour high-quality service User-friendly online submission system Fair and swift peer-review system Efficient typesetting and proofreading procedure Display of the result of downloads and visits, as well as the number of cited articles Maximum dissemination of your research work

Submit your manuscript at: http://papersubmission.scirp.org/ Or contact abb@scirp.org 